OPEN ACCESS

ISSN 2338-445X (online)

ISSN 2527-9246 (print)

Edited by:

Sulikah Asmorowati

Reviewed by:

Gede Sandiasa and Lely Indah

Mindarti

${ }^{*}$ Correspondence :

Erika Sari Yulianti

Erikasari61@gmail.com

Published :29 Maret 2021

Citation:

Yulianti ES et.al (2021)

ANALYSIS OF CAREER

DEVELOPMENT PROGRAMS AND

EMPLOYEE WORK MOTIVATION

IN MADIUN INSTITUTIONS.

JKMP (Jurnal Kebijakan dan

Manajemen Publik). 9:1.

doi: $10.21070 / j k m p . v 9 i 1.1561$

\section{Analysis Of Career Development Programs And Employee Work Motivation In Madiun Institutions}

\section{Analisis Program Pengembangan Karir Dan Motivasi Kerja Pegawai Pada Instansi Di Kota Madiun}

\author{
Erika Sari Yulianti*, Satrijo Budiwibowo, Elly Astuti \\ Universitas PGRI Madiun
}

\begin{abstract}
This study aims to determine the HR development program of employees through career development, motivation. This study uses a qualitative descriptive research Case Study with eight respondents, namely: Head of Agency, Head of Formation, Development and Administration of Personnel, Head of Education and Training, Head of Staff Mutation, and four Employees. The results of this study are that career development programs and systems implemented in 2018 are good enough but not perfect because they do not have a clear pattern that still follows the merits system of the government, and motivation can be said to be good because there are rewards to employees and relationships between employees conducive.
\end{abstract}

Keywords: Human Resources, Career Development Program, Motivation

\section{PENDAHULUAN}

Badan Kepegawaian Daerah merupakan salah satu instansi yang mempunyai tupoksi sebagai penyelenggara pengembangan karir menyeluruh dalam seluruh instansi Dinas Kota Madiun tidak hanya berfokuskan pada satu organisasi saja. Badan Kepegawaian Daerah Kota Madiun memiliki pegawai hasil mutasi dari intansi lain di Kota Madiun, mutasi tersebut terjadi ketika ada pegawai yang melakukan pengajuan mutasi dan memiliki kompetensi yang sesuai dengan bidang yang diampu. Dalam proses kenaikan pangkat terjadi ketika adanya formasi yang kosong serta adanya pegawai yang memiliki kompetensi yang sesuai kriteria yang telah ditetapkan, dan biasanya masa jabatan berlaku kurang lebih lima tahun.

Dari hasil data observasi, dalam Laporan Capaian Kinerja Triwulan IV pada tahun 2018 Badan Kepegawaian Daerah Kota Madiun dapat dijelaskan bahwa terdapat program-program pendukung berdasarkan target dan realisasi, namun dapat ditangkap salah satu permasalahan yaitu dimana Prosentase Peningkatan SDM Aparatur dituliskan dari 100\% target yang ingin dicapai namun hanya terealisasi $90.1 \%$. Hal tersebut dapat dilihat bahwa SDM tersebut juga berhubungan dengan pengembangan karir yang memiliki sasaran dalam meningkatkan kompetensi, pengetahuan dan keterampilan aparatur, dan juga BKD merupakan instansi yang memiliki tugas sebagai penyelenggara pengembangan karir di seluruh Karisidenan 
Kota Madiun, dengan demikian peneliti sangat tertarik akan hal-hal apa saja yang dilaksanakan BKD dalam mengembangkan karir pegawainya serta motivasi yang diberikan sebelum menyelenggarakan pengembangan karir di tingkat Pemerintah Kota Madiun.

Hasil penelitian yang dilakukan (Aryani, 2017) menjelaskan bahwa pengembangan karir PNS KPU di Kota Samarinda belum efektif dikarenakan belum ada badan diklat resmi untuk KPU dikarenakan kurangnya anggaran, sedangkan pada objek penelitian kali ini menunjukkan bahwa BKD telah melaksanakan program-program pelatihan untuk pengembangan karir secara baik dengan anggaran yang cukup, hal ini dikarenakan BKD merupakan tempat penyelenggara program diklat yang dilaksanakan di seluruh instansi Dinas Kota Madiun. Model pola pengembangan karir jabatan struktural pada Pemerintah Daerah Sulsel mengindikasikan bahwa pola pengembangan karir jabatan struktural harus dikembangkan lagi dengan tujuan semua persoalan mengenai pola karir pegawai negeri sipil dikelola dengan baik dan professional seperti yang diungkapkan oleh (Sukarno, 2018), sama halnya dengan pengembangan karir di BKD bahwa pengembangan karir telah dilaksanakan dengan baik dan rutin.

Dijelaskan pula hasil penelitian bahwa pelaksanaan program pelatihan dan pengembangan karyawan di PT Visi Sukses Bersama sudah terlaksana dengan baik (Haryati, 2019), begitu pula dengan BKD bahwa pengembangan karir pada pegawai sudah terlaksana dengan baik dengan terpilihnya beberapa pegawai yang telah memenuhi kriteria. Hasil penelitian (Kadarisman, 2018) menjelaskan proses pengembangan karier di Pemerintah Kota Depok para aparatur dapat membantu menentukan tujuan pengembangan karir untuk sasaran jabatan yang diinginkan, hal ini sama dengan BKD bahwa pegawai juga diberikan arahan dalam merencanakan pengembangan karir untuk mencapai jabatan. Pelaksanaan dalam meningkatkan kapasitas pegawai ASN dilaksanakan melalui promosi, beasiswa kedinasan, serta pelaksanaan diklat seperti yang dijelaskan oleh (Komara, 2019), sedangkan upaya BKD untuk melaksanakan pengembangan karir yaitu dengan diklat yang dilaksanakan oleh Pemerintah maupun pihak BKD sendiri.

Kepemimpinan dalam pengembangan karier memiliki peran sebagai mentor serta sponsor untuk pegawai seperti yang diungkapkan (Triatmanto, 2017), hal ini memiliki kesamaan dengan BKD bahwa sikap pemimpin memiliki pengaruh kepada pegawai sebagai pendorong atau seperti pihak eksternal yang memberikan motivasi kepada pegawainya. Pengembangan karier pada STAIN Curup perlu dilakukan suatu stretegi yang sesuai dan tepat seperti yang dijelaskan (Fathurrochman, 2017), berbeda halnya dengan BKD bahwa pengembangan karir sudah tertata dengan baik namun masih belum memiliki sistem yang sesuai dengan pola yang jelas.

Dalam pemberian motivasi, hasil penelitian (Sarina, 2016) menjelaskan bahwa peningkatan motivasi kerja oleh camat dalam pencapaian tujuan organisasi yaitu sudah berjalan dengan maksimal karena camat sudah bersikap tegas dalam setiap pemasalahan yang terjadi, pada objek penelitian di BKD pemberian motivasi kerja oleh Kepala Dinas sudah dilaksanakan hampir setiap harinya pada saat pembagian tugas dan pada saat rapat baik itu dilaksanakan secara formal maupun nonformal. Hal yang dapat menjadi motivasi dan dapat meningkatkan hasil kerja karyawan dapat dilakukan dengan memberikan gaji tambahan sesuai target yang dicapai, memberikan tempat tinggal yang nyaman, serta memberikan buku atau televisi dengan tujuan agar mereka bisa belajar diungkapkan dari hasil penelitian oleh (Pranoto, 2016). Namun berbeda halnya di BKD bahwa hal yang menjadi motivasi adalah kebanyakan pegawai sudah menjadi PNS karena mereka akan mengabdi pada Negara dengan berbagai tunjangan yang telah diberikan.

Perbedaan penelitian ini dengan penelitian yang lain yaitu pelaksanaan penelitian yang fokus pada program pengembangan karir serta pemberian motivasi kerja pada pegawainya, serta tahun penelitian yang dilaksanakan yaitu peneliti melakukan penelitian pada Tahun 2019. Berkaitan dengan meningkatnya tugas dari pemerintahan, maka diwajibkan bahwa kegiatan administrasi manajemen di Badan Kepegawaian Kota Madiun harus berjalan dengan baik dengan tujuan yang dapat dicapai serta terlaksana sesuai rencana yang sudah ditetapkan. Penelitian ini bertujuan untuk mengetahui bagaimana pengembangan karir dan pemberian motivasi kerja pada Badan Kepegawaian Daerah Kota Madiun. 


\section{Manajemen Sumber Daya Manusia}

(Mangkunegara, 2017) memberikan pendapat bahwa Manajemen Sumber Daya Manusia adalah pengelolaan dan pendayagunaan sumber daya yang ada pada individu (pegawai) guna untuk mencapai tujuan organisasi dengan cara pengelolaan dan pendayagunaan dikembangkan dengan maksimal dalam dunia kerja. Sumber Daya Manusia di suatu organisasi perlu dikelola dengan tujuan agar mewujudkan keseimbangan antara kebutuhan pegawai dengan apa yang diinginkan instansi tercapai dan berkembang.

Salah satu kebutuhan pegawai adalah adanya karir yang berjenjang untuk mendorong pegawai menampilkan performa terbaiknya ketika bekerja. Pengembangan suatu karir begitu penting bagi pegawai dengan tujuan meningkatkan kemampuan yang pada akhirnya akan memperoleh kehidupan kerja yang lebih baik dari sebelumnya. (Yusuf, 2015) menjelaskan bahwa pada intinya pengembangan karir dapat membantu pegawai dan juga perusahaan/instansi dalam mengembangkan diri individu dan organisasi.

(Yusuf, 2015) menjelaskan bahwa pengembangan karir secara individual dapat dilakukan dengan beberapa hal diantaranya melalui:

1. Prestasi Kerja yang merupakan salah satu aktivitas utama dalam mengembangkan suatu karir;

2. Exposure yaitu mereka yang mampu mempromosikan diri sehingga mendapatkan peluang karir yang lain;

3. Permintaan Berhenti dilakukan pegawai dengan maksud untuk mendapatkan tempat kerja yang lebih layak untuk mengembangkan karirnya;

4. Kesetiaan pada Organisasi yaitu dimana pegawai yang memiliki kesetiaan organisasi yang rendah akan dipersulit dalam mengembangkan karirnya di masa yang akan datang;

5. Mentor dan Sponsor dijelaskan bahwa mentor dapat menjadi sponsor untuk pegawai mereka dimana sponsor merupakan orang yang dapat memberikan kesempatan pengembangan karir bagi orang lain.

Sedangkan untuk pengembangan karir secara organisasional dapat dilakukan dengan:

1. Dukungan manajemen. Dukungan dari manajer/atasan merupakan hal yang dibutuhkan oleh departemen personalia untuk melaksanakan program pelatihan dan pengembangan yang sudah disusun. Tanpa adanya dukungan mustahil dapat dilaksanakan.

2. Umpan balik. Tanpa adanya umpan balik, karyawan akan merasa bahwa pengabdiannya yang telah dilakukan pada instansi tempat dia bekerja selama itu akan sia-sia saja.

Menurut (Hasibuan, 2018) ada beberapa metode pengembangan yang akan dilakukan oleh karyawan/pegawai adalah:

1. Metode latihan (training). Metode ini biasanya diberikan kepada karyawan/ pegawai operasional. Metode ini harus berdasarkan pada kebutuhan pekerjaan tergantung faktor, yaitu waktu, jumlah peserta, dan tingkatan pendidikan dasar peserta.

2. Metode pendidikan (education). Metode ini biasanya diberikan kepada karyawan/ pegawai manajerial atau biasa disebut dengan pemimpin/atasan dalam perusahaan maupun lembaga. 


\section{Motivasi}

Motivasi merupakan aspek lain yang turut mempengaruhi performa seorang karyawan. Motivasi merupakan pencapaian tujuan yang diharapkan dengan menggerakkan suatu energi individu untuk melakukan suatu usaha (Torang, 2014). Bila suatu individu termotivasi dari ucapan atau berupa apapun dia akan lebih menjadi pribadi yang kuat dan bertekad bulat atas keinginan yang akan dicapainya.

Menurut (Fahmi, 2017) motivasi itu muncul dalam dua bentuk yaitu:

1. Motivasi ekstrinsik (dari luar) motivasi ini bersumber atau muncul dari luar diri seorang individu, biasanya berasal dari orang lain yang memberikan pengarahan yang dapat menginspirasi dan mengubah hidupnya.

2. Motivasi instrinsik, motivasi ini bersumber dari dalam diri individu tersebut.

(Mangkunegara, 2017) menjelaskan prinsip-prinsip yang dapat diterapkan oleh organisasi untuk memberikan motivasi kepada pegawai, yaitu:

1. Prinsip partisipasi. Pegawai/karyawan memiliki kesempatan untuk ikut serta menentukan tujuan yang akan dicapai oleh organisasi.

2. Prinsip komunikasi. Pemberian informasi oleh pemimpin sebagai komunikasi kepada bawahan dengan pencapaian tugas dengan informasi yang jelas sebagai upaya untuk memotivasi pegawai/karyawannya.

3. Prinsip mengakui partisipasi bawahan. Pemimpin mengakui jika bawahannya turut ikut serta berpartisipasi dalam usaha organisasi dalam mencapai tujuan. Berdasarkan pengakuan tersebut akan memudahkan dalam memberikan motivasi pada pegawai/ karyawannya.

4. Prinsip mendelegasi wewenang. Pemberian wewenangan oleh pemimpin kepada pegawai/karyawannya untuk dapat mengambil keputusan atas pekerjaan yang dilakukannya. Pemberian wewenang dimaksudkan untuk memberikan dorongan kepada pegawai/karyawan agar segera mencapai tujuan yang diinginkan pimpinan.

5. Prinsip memberi perhatian. Pemimpin memberikan perhatian kepada pegawai/ karyawannya, apa yang mereka butuhkan dan inginkan. Pemberian perhatian ini diupayakan untuk pegawai/karyawan agar lebih termotivasi untuk melakukan pekerjaan. 
Gambar 1.

Kerangka Pemikiran

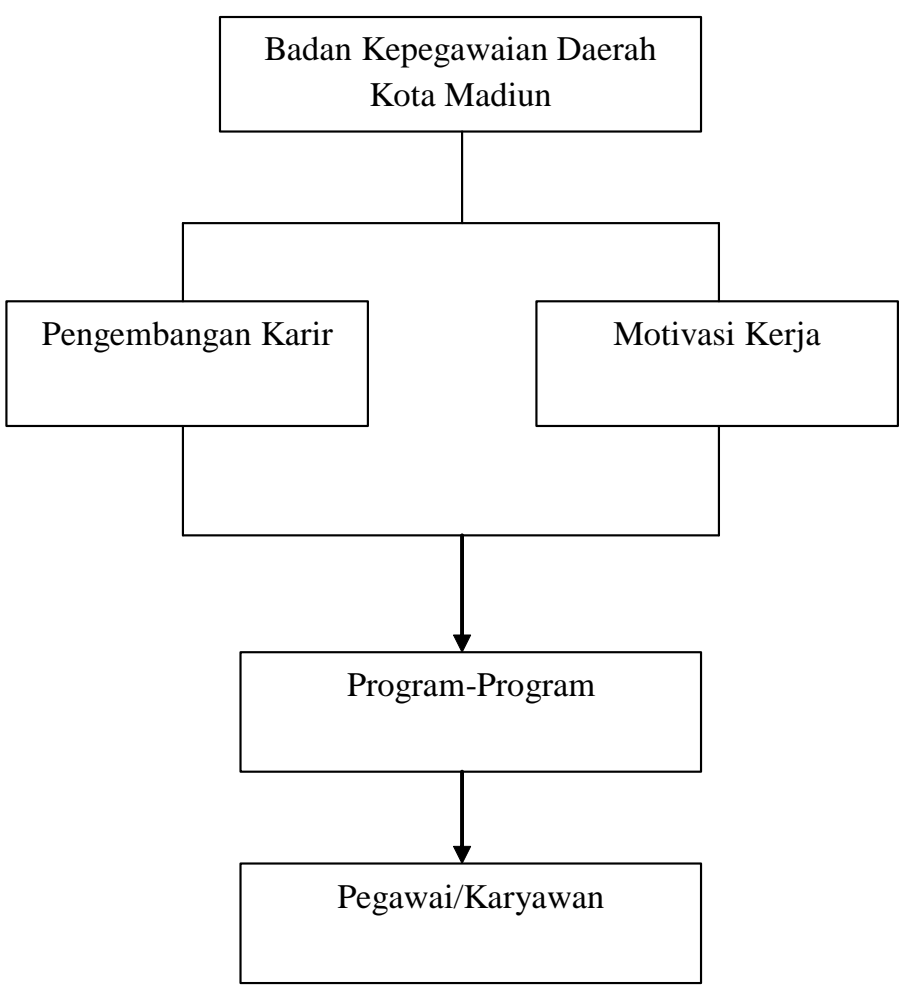

\section{METODE PENELITIAN}

Penelitian ini merupakan jenis penelitian kualitatif deskriptif Studi Kasus karena diperlukan data-data yang diambil secara langsung serta mengamati prosesnya secara langsung. Pengumpulan data dalam penelitian ini yaitu menggunakan data primer yang didapatkan dari wawancara tidak terstruktur dengan delapan informan yaitu Kepala Badan, Kabid Formasi, Pengembangan dan Administrasi Kepegawaian, Kabid Pendidikan dan Pelatihan, Kabid Mutasi Kepegawaian, dan empat Pegawai, dan data sekunder berupa berupa dokumen seperti, data pegawai digunakan untuk mengetahui berapa jumlah pegawai yang ada di BKD, struktur organisasi untuk mengetahui bagaimana susunan struktur organisasi di BKD, program kerja untuk mengetahui apa saja program kerja yang dilaksanakan BKD pada tahun 2018, tugas pokok dan fungsi untuk mengetahui apa tugas dari BKD, SOP untuk mencocokan data yang didapatkan apakah sesuai dengan standar, dan data-data lainnya yang berkaitan dengan pengembangan karir, motivasi kerja pegawai serta dokumentasi dalam proses penelitian dan pengumpulan data

Proses analisis data dalam peneltitian ini yaitu pengumpumpulan data dengan menggunakan teknik observasi lapangan dengan mendatangi langsung Kabid Mutasi Pegawai yaitu observasi untuk mengetahui bagaimana proses kenaikan jabatan di BKD, KasubBag Perencanaan dan Kepegawaian untuk mengetahui program-program yang dilaksanakan BKD dalam melaksanakan pelatihan untuk pengembangan karir serta persen realisasi Laporan Capaian Kinerja, KasubBid Diklat Kepemimpinan, Fungsi dan Teknologi yaitu observasi tentang bagaimana pelatihan diklat pengembangan karir di BKD, Kasubbid Formasi dan Pengembangan Karier Pegawai untuk mengetahui daftar program pelatihan untuk pengembangan karir yang telah dilaksanakan oleh Pemerintah Pusat maupun pihak- 
BKD, dan dokumentasi dalam penelitian memerlukan beberapa data yang dibutuhkan dari Sub Bagian Perencanaan \& Kepegawaian dan Bidang Diklat Kepemimpinan, Fungsi \& Teknologi untuk mendapatkan data-data berupa: dokumen struktur organisasi, dokumen tugas pokok dan fungsi, program kerja, dokumen program pendidikan dan pelatihan (diklat), dokumen jumlah karyawan yang aktif dan yang sudah pensiun, laporan capaian kinerja, serta foto pada saat pelaksanaan wawancara dan hasil wawancara. Dari data-data yang sudah terkumpul nantinya akan dianalisis, dicocokan dan ditarik kesimpulan.

\section{HASIL DAN PEMBAHASAN}

Jenjang karir dalam Badan Kepegawaian Daerah Kota Madiun dapat dikatakan sangat diperhatikan yaitu disaring dengan ketentuan-ketentuan dari PP11 2017 tentang Manajemen Pegawai Negeri Sipil yaitu menentukan syarat yang harus dimiliki sesuai dengan kualifikasi, kompetensi, penilaian kinerja, dan kebutuhan instansi. Jenjang karir dalam Badan Kepegawaian Daerah Kota Madiun dapat dijelaskan bisa dilalui dari awal sesuai dengan urutan dan bisa dilalui dengan langsung melompat ke jenjang yang lebih tinggi. PP11 2017 tentang Manajemen Pegawai Negeri Sipil Pasal 180 Rencana Pengembangan Karir menjelaskan bahwa rencana pengembangan karir disusun untuk jangka waktu 5(lima) tahun. Namun juga bisa jadi 2-3 tahun jika pegawai tersebut memiliki ketentuan yang sesuai dengan yang diminta instansi dan tidak harus urut sesuai dengan urutan kepangkatan dari bawah ke paling atas, jika sudah memiliki kriteria yang sudah ditentukan maka pihak instansi tidak akan memandang dari lama tidaknya bekerja dan memiliki kualitas yang baik maka bisa langsung naik jabatan. Untuk jabatan yang paling tinggi yaitu sebagai Kepala Badan, pengembangan karir masih berlaku untuk menuju ke jenjang karir yang lebih tinggi yaitu berkarir di tingkat Kota/Kabupaten sebagai Sekretaris Daerah. Hal ini dibuktikan dengan wawancara pada informan satu yang menjelaskan "Ada syarat yang sudah ditentukan di ketentuan PP11 2017 tentang Manajemen Pegawai Negeri Sipil yang menentukan beberapa jabatan yang paling bawah yang Excellent 4 iyaitu sebagai Pengawas, yang meliputi syarat kualifikasi akademik, golongan, pengalaman kerja, kompetensi, tetapi tidak harus urut maksudnya ketika ada pegawai yang sudah memiliki syarat-syarat yang sudah ditentukan dan tidak memandang dari faktor lama tidaknya bekerja dan memiliki kualitas yang baik maka bisa langsung naik jabatan". Dan wawancara dengan informan dua sebagai berikut "Kalau untuk Kepala Badan itu memiliki masa jabatan 5 tahun tapi kalau untuk yang lainnya itu dinamis, tergantung kompetensi yang dimiliki bisa jadi 2-3 tahun atau bahkan lebih".

Program kegiatan pengembangan karir yang dilaksanakan pada Badan Kepegawaian Daerah Kota Madiun salah satunya adalah diklat Teknis dan fungsional yaitu jenis diklat yang dilaksanakan untuk mencapai persyaratan kompetensi yang sesuai dengan jenis dan jenjang jabatan fungsional masing-masing dan diklat teknis yaitu dilaksanakan untuk memenuhi persyaratan kompetensi yang diperlukan untuk pelaksanaan tugas para PNS. Untuk Bimtek/Sosialisasi/Workshop dilaksanakan untuk mengembangkan atau meningkatkan kapasitas sumber daya aparatur, dan juga ada program Assessment Pegawai.

Assessment Pegawai merupakan suatu metode yang digunakan untuk mengukur kompetensi seseorang dengan menggunakan manajemen talentpool. Dalam BKD program yang sudah dilaksanakan yaitu program Assessment Center yaitu metode untuk mengukur kompetensi seseorang dengan kebijakan talentpool yaitu mengelompokkan jabatan tinggi pratama sampai dengan jabatan pengawas. hal ini didukung oleh pernyataan informan yaitu" program yang sudah dilaksanakan BKD adalah program Assessment Center dengan menggunakan kebijakan talentpool yang mengelompokkan jabatan tinggi pratama sampai dengan jabatan pengawas. Jabatan tinggi pratama itu seperti Kepala Dinas, Kepala Badan, Asisten Daerah. Lalu ada jabatan administrasi itu ada tiga yaitu jabatan administrator, pengawas, dan pelaksana. Program itu sudah mulai dilaksanakan sejak tahun 2016, 2017, $2018 "$. 
Tabel 2. Program dan Kegiatan Tahun Rencana Tahun 2018

\begin{tabular}{|c|c|c|}
\hline No & Program & Kegiatan \\
\hline 1. & $\begin{array}{l}\text { Program Peningkatan } \\
\text { Manajemen Pelayanan } \\
\text { Administrasi Kepegawaian }\end{array}$ & $\begin{array}{ll}\text { a. } & \text { Pelayanan Administrasi } \\
& \text { Kepegawaian } \\
\text { b. } & \text { Operasional dan pemeliharaan } \\
& \text { SIMPEG dan SAPK }\end{array}$ \\
\hline 2. & $\begin{array}{l}\text { Program Pembinaan dan } \\
\text { Pengembangan Aparatur }\end{array}$ & $\begin{array}{ll}\text { a. Seleksi penerimaan Calon Pegawai } \\
\text { Sipil } \\
\text { b. Ujian kenaikan pangkat } \\
\text { penyesuaian ijazah } \\
\text { c. Penyelesaian masalah } \\
\text { Kepegawaian dan Pembinaan } \\
\text { Pegawai } \\
\text { d. Pemberian Penghargaan bagi PNS } \\
\text { yang berprestasi }\end{array}$ \\
\hline 3. & $\begin{array}{l}\text { Program Peningkatan } \\
\text { Kapasitas Sumber Daya } \\
\text { Aparatur }\end{array}$ & $\begin{array}{ll}\text { a. } & \text { Diklat Teknis dan Fungsional } \\
\text { b. } & \text { Bimtek/ Sosialisasi/ Workshop } \\
& \text { Pengembangan Aparatur } \\
\text { c. } & \text { Assessment Pegawai } \\
\text { d. } & \text { Diklat Kepemimpinan Tk. II } \\
\text { e. } & \text { Diklat Kepemimpinan Tk. III } \\
\text { f. } & \text { Diklat Kepemimpinan Tk. IV }\end{array}$ \\
\hline 4. & $\begin{array}{l}\text { Program Fasilitasi Peningkatan } \\
\text { Kesejahteraan PNS }\end{array}$ & $\begin{array}{l}\text { a. Penataan Sistem Administrasi } \\
\text { Kenaikan Pangkat dan Kenaikan } \\
\text { Gaji Berkala } \\
\text { b. Pemberhentian PNS yang Pensiun } \\
\text { a. Penataan Pegawai }\end{array}$ \\
\hline
\end{tabular}

Tabel tersebut telah menunjukkan bahwa Badan Kepegawaian Daerah Kota Madiun telah melaksanakan berbagai macam program dengan banyak kegiatan contohnya seperti Program Pembinaan dan Pengembangan Aparatur dengan kegiatan pemberian penghargaan bagi PNS yang berprestasi pada BKD sudah dilaksanakan dan ada beberapa pegawai yang sudah mendapatkan penghargaan telah sesuai dengan ungkapan responden dalam wawancara yang telah dilaksanakan. Program peningkatan kapasitas sumber daya aparatur yaitu dengan dilaksanakannya Bimtek/Sosialisasi/Workshop Pengembangan Aparatur juga telah dilaksanakan sesuai dengan jawaban responden pada saat dilaksanakannya wawancara.

Pada program fasilitasi Peningkatan Kesejahteraan PNS terdapat kegiatan yaitu penataan sistem administrasi kenaikan pangkat dan kenaikan gaji berkala. Data wawancara responden mengatakan bahwa sistem masih belum bisa dibilang cukup sempurna, masih dalam proses. Begitupun untuk sistem pengembangan karir yang ada pada BKD juga belum bisa dikatakan belum sempurna belum bisa sesuai berdasarkan meritsistem. Meritsistem merupakan sistem penilaian kinerja berdasarkan atas profesionalisme dan latarbelakang kemampuan intelektual seseorang, walaupun standart yang ditetapkan dari Kementrian MENPAN mungkin masih jauh, upaya BKD untuk mewujudkannya yaitu dengan berbagai tes kompetensi, menilai dari karakter seseorang untuk menyusun karir seseorang yang bisa diberi nilai apakah seseorang itu mampu ataukan layak untuk diberi suatu jabatan. 
Tabel 3. Rencana dan Realisasi Kegiatan Tahun Rencana Tahun 2018

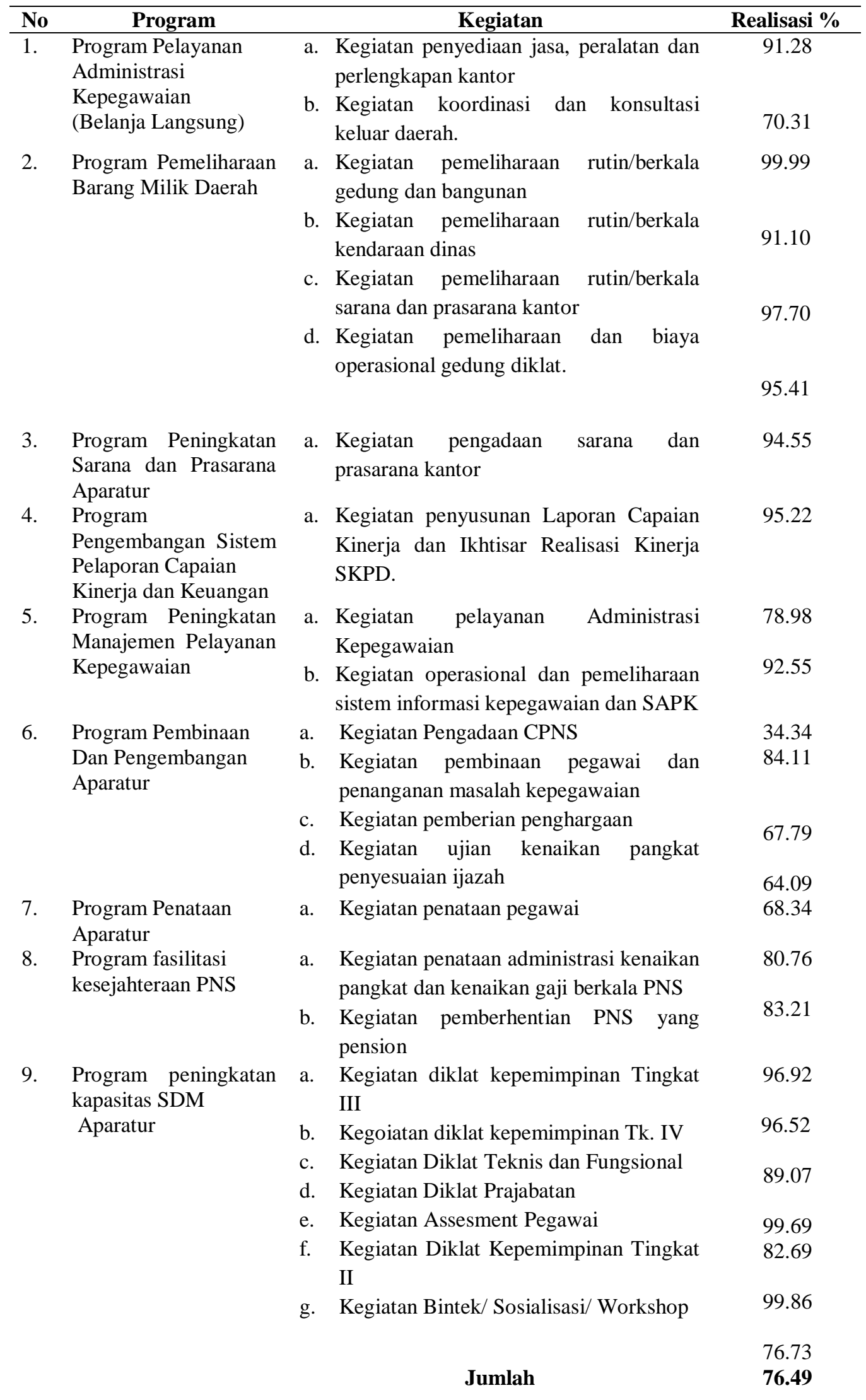


Dari tabel tersebut dapat diketahui bahwa semua program yang direncanakan telah terlaksana dengan realisasi keseluruhan program di Badan Kepegawaian Daerah Kota Madiun adalah $76.49 \%$ dari $100 \%$ target yang akan dicapai. Terlebih tentang program yang menyangkut tentang peningkatan SDM aparatur seluruh kegiatan sudah terealisasi hampir $100 \%$.

Banyak dari responden yang menyatakan dalam pencapaian suatu prestasi yaitu adanya reward atau penghargaan dengan tujuan dapat meningkatan kinerja dapat menjadi motivasi dalam diri pegawai. Selanjutnya dalam hubungan antar pegawai di BKD menjadi motivasi bagi pegawai bahwa mereka dapat melakukan hubungan lebih baik lagi dengan mengembangkan kompetensinya, hal ini terjadi pada BKD dimana pegawai dengan atasan memiliki hubungan yang sangat baik maka akan memudahkan pegawai dalam mengembangkan karirnya. Hal ini diperkuat dalam argumen informan yaitu "Baik mba, kekeluargaannya juga bagus. hal ini akan menunjang motivasi pada pegawai supaya lebih bersemangat lagi kedepannya".

\section{Program-program yang dilaksanakan pada Badan Kepegawaian Daerah Kota Madiun}

Penjelasan diatas merupakan hasil data dan temuan peneliti dalam pelaksanaan penelitian, selanjutnya peneliti menjelaskan bagian pembahasan dari hasil yang telah didapatkan di lapangan. Telah dijelaskan diatas bahwa BKD telah melaksanakan program kegiatan yang disusun pada tahun 2018 meskipun tidak keseluruhan tercapai, namun program yang belum dapat terlaksana akan dilanjutkan pada tahun 2019 mendatang bersama dengan rencana kerja baru. Pernyataan ini didukung oleh hasil wawancara dengan informan yaitu "ya kalau untuk tercapai semua ya belum keseluruhan mbak, pas ada program yang belum tercapai diikutkan pada tahun berikutnya” dan juga didukung oleh data Realisasi Program Kegiatan BKD. 
Tabel 4 Laporan Capaian Kinerja Prosentase Target dan Realisasi Program Tahun 2018

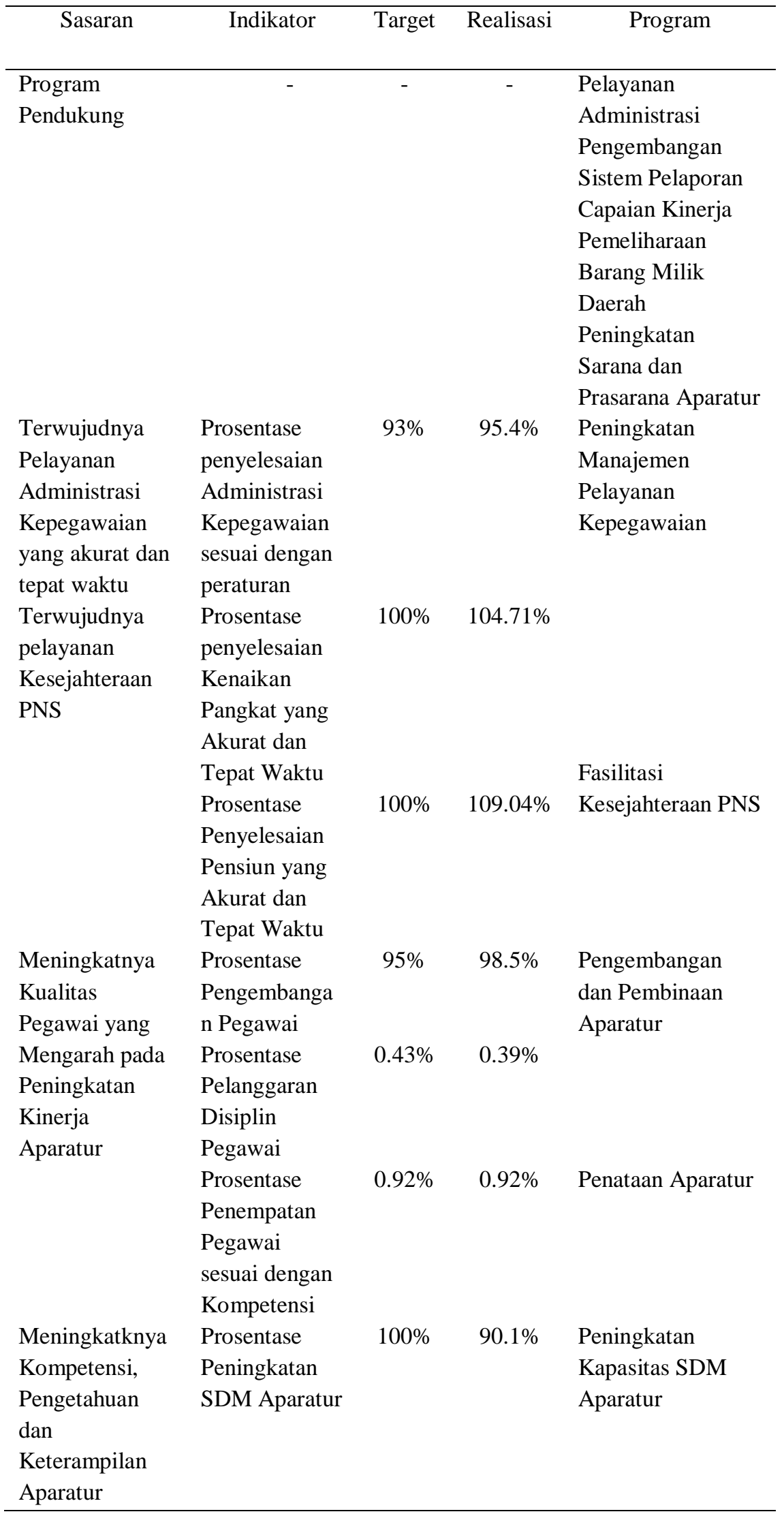


Prosentase penyelesaian Administrasi Kepegawaian sesuai dengan peraturan telah terealisasi $95.4 \%$ dari target $93 \%$. Maksud dari penyelesaian yang sesuai dengan peraturan disini adalah Peraturan Pemerintah Nomor 11 Tahun 2017 pasal 52 yaitu seluruh kegiatan yang telah direncanakan dengan baik yang sesuai dengan standar operasional prosedur dan terselenggara peningkatan kinerja secara berkesinambungan, bagi jabatan administrator. Capaian kinerja tersebut telah naik bila dibandingkan dengan pencapaian kinerja sasaran pada tahun 2017 yaitu 91.5\%. Capaian Indikator ini lebih tinggi apabila dibandingkan dengan target tahunan pada Renstra yaitu 93\%. Untuk prosentase penyelesaian kenaikan pangkat yang akurat dan tepat waktu yaitu $104.71 \%$ dari $100 \%$ telah melebihi target yang telah ditetapkan apabila dibandingkan dengan capaian kinerja tahun 2017 yang sebesar $97.19 \% \%$, indikator ini mengalami kenaikan. Apabila dibandingkan dengan target yaitu $100 \%$, capaian kinerja indikator ini sedikit berkurang. Untuk prosentase penyelesaian pensiun yang akurat dan tepat waktu terealisasi $109.04 \%$ dari target $100 \%$. Maksud dari pangkat dan penyelesaian pensiun yang akurat dan tepat waktu adalah sesuai dengan Standar Operasional Prosedur Baperjakat dari Surat Keputusan Walikota yang berlandaskan Pada Peraturan Pemerintah No 12 Tahun 2002 Pasal 7. Capaian kinerja tersebut sedikit kurang jika dibandingkan dengan pencapaian kinerja sasaran tahun 2017 yaitu 111.11\%. Dimana kenaikan capaian kinerja dibanding target disebabkan bertambahnya usulan pensiun Janda/Duda lebih dari yang diperkirakan.

Prosentase pengembangan pegawai dalam pengembangan dan pembinaan aparatur dituliskan bahwa ditargetkan $95 \%$ telah terealisasi $98.5 \%$. Indikator ini berhubungan dengan pengembangan pegawai di lingkungan Pemerintah Kota Madiun. Kegiatan yang dimaksud adalah Penerimaan CPNS dan Kegiatan Ujian Dinas. Pada Tahun 2018 BKD menyelenggarakan ujian dinas tingkat I dan II dengan peserta sebanyak 30 PNS dari target sebanyak 25 PNS, capaiannya adalah $120 \%$. Sedangkan untuk kegiatan penerimaan CPNS berupa Penyelenggaraan Ujian Seleksi CPNS dengan peserta sebanyak 3054 peserta dari target sebanyak 4000 peserta atau $76.35 \%$. Dari dua kegiatan tersebut dicapai Indikator Prosentase Pengembangan Pegawai sebesar 98.5\%.

Tabel 5 Perbandingan Hukuman Disiplin Tahun 2016-2018

\begin{tabular}{ccccc}
\hline No & Uraian & $\mathbf{2 0 1 6}$ & $\mathbf{2 0 1 7}$ & $\mathbf{2 0 1 8}$ \\
\hline 1. & Hukuman Disiplin Berat & 4 & 4 & 7 \\
2. & Hukuman Disiplin Sedang & 5 & 4 & 3 \\
3. & Hukuman Disiplin Ringan & 3 & 1 & 3 \\
4. & Hukuman Disiplin Berat & 4 & 4 & 7 \\
& Jumlah & $\mathbf{1 2}$ & $\mathbf{9}$ & $\mathbf{1 3}$ \\
\hline
\end{tabular}


Untuk prosentase pelanggaran disiplin telah menunjukkan $0.39 \%$ realisasi dari perkiraan pelanggaran $0.43 \%$, jadi pelanggaran disiplin dapat dikatakan termasuk rendah. Pada Tahun Anggaran 2018 didapatkan data pelanggaran disiplin pegawai sebanyak 13 kasus dari 3.309 PNS, sehingga indikator ini bernilai $0.39 \%$. Pelanggaran yang dimaksud adalah hukuman disiplin berat, hukuman disiplin sedang, dan hukuman disiplin ringan. Pelanggaran tersebut termasuk telatnya pegawai pada saat datang ke kantor dengan jam operasional kantor pukul 07.30 dengan jumlah pelanggar yang sedikit yaitu sekitar 2-3 orang, dan pada saat jam istirahat kantor pukul 12.00 yaitu dengan ijin pergi istirahat meninggalkan kantor tanpa kembali lagi.

Program Peningkatan Kapasitas SDM Aparatur dituliskan bahwa total dari target 100\% hanya terealisasi $90.1 \%$. Hal ini bisa diartikan bahwa belum maksimalnya peningkatan SDM pada tahun 2018 dikarenakan ada beberapa faktor penghambat yaitu: a) penyelenggaraan/ penyelesaian kegiatan mengikuti jadwal dari instansi pusat; b) kebijakan mutasi dibatasi oleh Peraturan Pemerintah; c) Pengiriman Peserta diklat teknis/ fungsional menyesuaikan penawaran; d) proses penerimaan CPNS dilaksanakan s/d akhir tahun.

Tabel 6 Anggaran Program Tahun 2018

\begin{tabular}{|c|c|c|c|c|}
\hline \multicolumn{3}{|c|}{ Program } & Anggaran & Realisasi \\
\hline \multicolumn{3}{|c|}{ Pelayanan Administrasi } & 1.211 .172 .950 & 957.670 .322 \\
\hline $\begin{array}{l}\text { Pengembangan } \\
\text { Capaian Kinerj }\end{array}$ & Sistem & Pelaporan & 29.230 .560 & 27.834 .692 \\
\hline \multicolumn{3}{|c|}{ Pemeliharaan Barang Milik Daerah } & 216.305.660 & 207.221.669 \\
\hline $\begin{array}{l}\text { Peningkatan } \\
\text { Aparatur }\end{array}$ & Sarana dan & Prasarana & 128.800 .000 & 121.774 .610 \\
\hline $\begin{array}{l}\text { Peningkatan } \\
\text { Kepegawaian }\end{array}$ & Manajemen & Pelayanan & 163.665 .000 & 144.460 .197 \\
\hline \multicolumn{3}{|c|}{ Fasilitasi Kesejahteraan PNS } & 217.422.080 & 177.997.166 \\
\hline \multicolumn{3}{|c|}{ Pengembangan dan Pembinaan Aparatur } & 959.128 .470 & 358.308 .273 \\
\hline \multicolumn{3}{|c|}{ Penataan Aparatur } & 238.256 .040 & 162.825 .305 \\
\hline \multicolumn{3}{|c|}{ Peningkatan Kapasitas SDM Aparatur } & 2.002 .992 .040 & 1.794.087.282 \\
\hline \multicolumn{3}{|l|}{ Jumlah } & 9.125 .893 .240 & 7.580.275.571 \\
\hline
\end{tabular}

Anggaran yang dianggarkan lebih besar dari anggaran pada tahun 2017, Dari anggaran 9.125.893.240 dan masih tersisa 7.580.275.571. Seperti pada tahun 2017 bahwa sisa anggaran yang berjumlah 1.545.617.669 akan dikembalikan pada kas. Dari besarnya anggaran yang dianggarkan oleh Badan Kepegawaian Daerah Kota Madiun dapat dilihat bahwa pegawai termotivasi tidak dengan besarnya anggaran yang diberikan, namun memang termotivasi untuk meningkatkan kinerja.

Beberapa informan lain menyatakan berupa hasil wawancara yaitu,"gini mbak menjadi PNS itu memang impian, tapi kita tetap harus bekerja sesuai dengan aturan. Kesejahteraan sudah terjamin juga". Informan lain menyatakan pendapatnya yaitu "sebagai staff kita bekerja sesuai aturan yang ada mbak, mengikuti alur apa yang dikatakan ya kita kerjakan, saya sudah bekerja lama disini jadi ya lumayan bagus lah.” Jadi dapat disimpulkan bahwa pegawai Badan Kepegawaian Daerah Kota Madiun lebih termotivasi meningkatkan kompetensi dan keahlian untuk kinerja karena penghargaan yang didapatkan tidak selalu soal uang namun juga peningkatan pangkat, dan ada juga yang mendapatkan penghargaan SatyaLanca Karya Satya yaitu penghargaan bagi pegawai yang sudah bekerja selama lebih dai 10 tahun dengan mengembangkan berbagai kompetensi dan keahliannya. 


\section{Sistem Pengembangan Karir yang digunakan di Badan Kepegawaian Daerah Kota Madiun}

Dari analisis data yang sudah dijelaskan di bab sebelumnya bahwa jenjang karir yang dilaksanakan di BKD dari posisi jabatan yang paling bawah menuju ke atas yaitu dengan mutasi dan jalur umum, dalam Peraturan Presiden Paragraf 6 Tentang Mutasi Pasal 190 menjelaskan bahwa mutasi menggunakan waktu yang paling singkat 2 (dua) tahun dan 5 (lima) tahun. Mutasi dapat diajukan oleh pegawai yang bersangkutan itu sendiri dengan memiliki kompetensi yang sesuai dengan kriteria, dan bisa juga mutasi dari pihak atasan/instansi. Mutasi dapat diajukan oleh pegawai yang bersangkutan itu sendiri dengan memiliki kompetensi yang sesuai dengan kriteria, dan bisa juga mutasi dari pihak atasan/instansi. Untuk jalur umum bisa naik pangkat setingkat lebih tinggi sesuai dengan Peraturan Pemerintah Nomor 12 Tahun 2002 tentang Perubahan Peraturan Pemerintah Nomor 99 Tahun 2000 Tentang Kenaikan Pangkat Pegawai Negeri Sipil yaitu berbunyi Pasal 12 yang berbunyi "Pegawai Negeri Sipil yang menduduki jabatan struktural dan pangkatnya masih satu tingkat di bawah jenjang pangkat terendah yang ditentukan untuk jabatan itu, dapat dinaikkan pangkatnya setingkat lebih tinggi".

Kenaikan pangkat juga bisa terjadi ketika ada formasi yang kosong dan sesuai dengan kompetensi yang ditentukan sebagaimana yang telah dituliskan pada Peraturan Pemerintah No 33 Tahun 2011 Pasal 2 Nomor 3 yang berbunyi "Kenaikan pangkat sebagairnana dirnaksud pada ayat (I), dapat diberikan apabila: adanya formasi yang lowong; lulus ujian penyesuaian kenaikan pangkat. Dan hasil wawancara pada bagian diklat menyampaikan "kenaikan pangkat ya tergantung ya kalau disini biasanya nunggu ada formasi yang kosong yang dibutuhkan instansi, bisa jadi mutasi dari instansi lain."

Salah satu informan juga memberikan pernyataan sebagai berikut "Ada syarat yang sudah ditentukan di ketentuan PP11 2017 tentang Manajemen Pegawai Negeri Sipil yang menentukan beberapa jabatan yang paling bawah yang Excellent 4 yaitu sebagai Pengawas, yang meliputi syarat kualifikasi akademik, golongan, pengalaman kerja, tetapi tidak harus urut maksudnya ketika ada pegawai yang sudah memiliki syarat-syarat yang sudah ditentukan dan tidak memandang dari faktor lama tidaknya bekerja dan memiliki kualitas yang baik maka bisa langsung naik jabatan". Untuk masa jabatan yaitu berlaku $\leq 5$ (lima) hal ini dibuktikan dengan pernyataan informan "Kalau untuk Kepala Badan itu memiliki masa jabatan 5 tahun tapi kalau untuk yang lainnya itu dinamis, tergantung kompetensi yang dimiliki bisa jadi 2-3 tahun atau bahkan lebih".

Berdasarkan hasil dari wawancara oleh enam informan yaitu empat dari enam informan menjelaskan bahwa belum terdapat sistem yang dapat dikatakan sempurna. BKD saat ini masih berpedoman pada meritsistem, dimana pengembangan karir di BKD itu belum ada suatu pola yang sudah tertuang dalam suatu peraturan Kepala BKD. Masih melihat secara penilaian, pada intinya belum memiliki pola yang jelas. Sistem standar kompetensi jabatan dijelaskan pada Peraturan Kementrian MENPAN Tentang Standar Kompetensi Jabatan Aparatur Sipil Negara Pasal 1. Hal ini dibuktikan dengan hasil wawancara dengan informan satu "kalau mau dibilang baik sih saya rasa masih jauh, tetapi kami berupaya untuk mengarah ke sana, kita sudah melakukan penilaian sistem karir berdasarkan meritsistem walaupun standart yang ditetapkan dari Kementrian MENPAN mungkin masih jauh, kadang berupaya untuk mewujudkannya dengan berbagai tes kompetensi, dan menilai dari karakter seseorang untuk menyusun karir seseorang yang bisa kita nilai apakah seseorang itu mampu ataukan layak untuk diberi suatu jabatan. Jadi meritsistem merupakan sistem penilaian kinerja berdasarkan atas profesionalisme dan latarbelakang kemampuan intelektual seseorang". Dan diperkuat dari hasil wawancara informan dua yang menjelaskan "kalau dikatakan baik sudah karena sudah tertata, tapi kalau sesuai dengan meritsistem masih belum". 


\section{Peran Badan Kepegawaian Daerah dalam Memberikan Motivasi Kepada Pegawai Dalam Usaha Mencapai Prestasi}

Badan Kepegawaian Daerah dalam pemberian motivasi dalam usaha mencapai sebuah prestasi yaitu dengan memberikan hadiah berupa jabatan atau reward berupa penghargaan Satyalancana Karya Satya, dengan kemampuan yang dimilikinya dalam peningkatan kinerja. Biasanya Penghargaan Satyalancana Karya Satya diberikan kepada pegawai dengan masa kerja selama 10-30 tahun dengan menunjukkan kedisiplinan, kesetiaan, kecakapan, sehingga dapat dijadikan teladan. BKD juga memberikan motivasi ketika ada waktu ketika rapat, ketika bertemu dikantor dan tidak harus formal. Hal ini diperkuat berdasarkan hasil dari wawancara dari informan satu "Ya, setiap saat setiap ada kesempatan dan tidak harus formal, dan juga pada saat ada rapat resmi, dan juga apel pagi, dan juga setiap saat ketemu sebelum sholat dzuhur ataupun setelah itu, ketika ada diruangan itu saya berikan motivasi". Diperkuat lagi dengan hasil wawancara informan dua yang menjelaskan "Ya sering sekali diberikan motivasi, yaitu seperti rapat dinas, dimana pimpinan memberi arahan. Biasanya minimal satu bulan sekali".

\section{Peran Badan Kepegawaian Daerah Dalam Memberikan Motivasi Kepada Pegawai Untuk Membangun Hubungan yang Antar Pegawai}

Badan Kepegawaian Daerah dalam pemberian motivasi kepada pegawai untuk membangun hubungan yang baik antar pegawai yaitu dibuktikan dari hasil wawancara dimana terdapat hubungan antar pegawai dan atasan yang dapat dibilang cukup baik atau kondusif. Dibuktikan dengan adanya program kegiatan yang mengumpulkan seluruh pegawai mulai dari jabatan paling atas sampai bawah dan biasanya dilaksanakan setiap satu bulan sekali. Dan juga pelaksanaan diklat-diklat yang dilaksanakan oleh Badan Kepegawaian Daerah Kota Madiun. Hal ini juga diperkuat dari hasil wawancara dengan informan satu yaitu "Bagus. Disini juga ada forum kebersamaan staff. Jadi kita menyerahkan program perencanaan evaluasinya sampai mana dengan menghadirkan seluruh pegawai di BKD mulai dari pimpinan hingga staff."

Terdapat program kegiatan yang mengumpulkan seluruh pegawai mulai dari jabatan paling atas sampai bawah dan biasanya dilaksanakan setiap satu bulan sekali. Dan juga pelaksanaan diklat-diklat yang dilaksanakan oleh Badan Kepegawaian Daerah Kota Madiun.

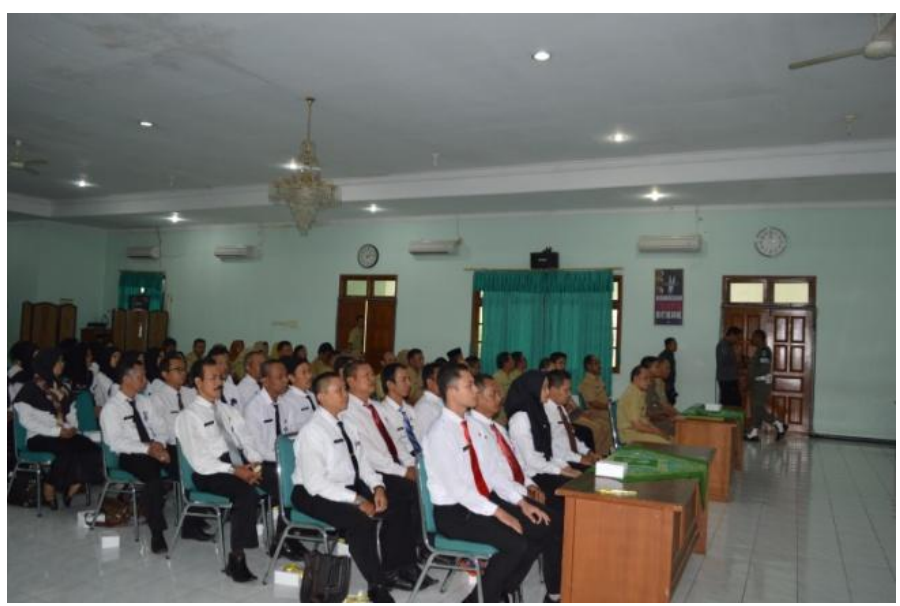

Gambar 1 Diklat Kearsipan BKD 


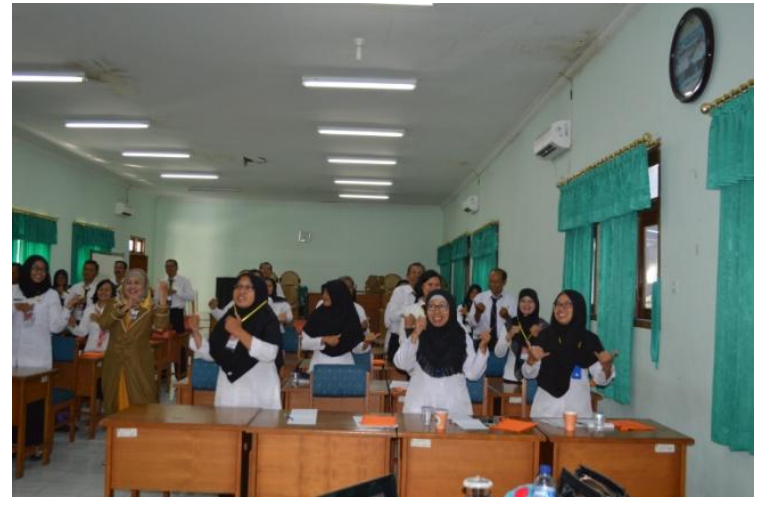

Gambar 2 Diklat Perubahan Mindset

Gambar berikut merupakan foto dokumentasi saat pelaksanaan kegiatan diklat oleh Badan Kepegawaian Daerah Kota Madiun yang mengumpulkan seluruh pegawai yang menggambarkan bahwa hubungan pegawai Badan Kepegawaian Daerah Kota Madiun dengan pegawai internal ataupun eksternal terjalin cukup harmonis. Demikian kekeluargaan antar pegawai tumbuh yang nantinya dapat menciptakan lingkungan yang kondusif dan nyaman yang akan mempengaruhi kinerja kedepannya.

\section{Peran Badan Kepegawaian Daerah Dalam Memberikan Motivasi Kepada Pegawai Dalam Mencapai Target Yang Telah Ditetapkan Terkait Dengan Kebutuhan Akan Kekuasaan}

Badan Kepegawaian Daerah dalam pemberian motivasi kepada pegawai untuk mencapai target yang telah ditetapkan terkait dengan kebutuhan akan kekuasaan yaitu dibuktikan dengan hasil wawancara bahwa pegawai harus memiliki syarat yang sudah ditentukan di ketentuan PP11 2017 tentang Manajemen Pegawai Negeri Sipil dimana pegawai yang sudah memiliki syarat-syarat yang sudah ditentukan bisa langsung naik jabatan. Dijelaskan bahwa pegawai yang akan dinaikkan jabatannya harus memiliki kriteria yang tercantum di PP11 2017 yaitu biasanya pegawai yang memiliki kompetensi yang cukup memadai dan meskipun dia baru bekerja beberapa tahun, dapat langsung diberikan jabatan yang sesuai. 


\section{KESIMPULAN DAN SARAN}

\section{Simpulan}

Berdasarkan hasil penelitian dan pembahasan yang telah diuraikan sebelumnya, dapat disimpulkan bahwa hasil dari penelitian ini adalah program dan sistem pengembangan karir yang dilaksanakan pada Tahun 2018 sudah cukup baik namun belum sempurna karena belum memiliki pola yang jelas masih mengikuti pola meritsistem dari pemerintah, dan pemberian motivasi dapat dikatakan baik karena ada pemberian reward kepada pegawai serta hubungan antar pegawai yang kondusif. Keterbatasan dalam penelitian ini adalah adanya keterbatasan akses informasi atas data yang diperlukan pada BKD terkait realisasi program pada tahun 2018 dan pihak BKD hanya memberikan sebagian tidak keseluruhan namun masih bisa dijadikan bukti penelitian.

\section{Saran}

Saran bagi peneliti selanjutnya yang menggunakan objek yang sama supaya bisa melaksanakan penelitian lebih baik lagi dengan menggunakan topik penelitian yang berbeda serta pembahasan yang spesifik, dengan menggunakan teknik penelitian triangulasi waktu agar lebih memperkuat kevalidan data yang didapatkan.

\section{PENDANAAN}

Publikasi artikel ini menggunakan dana pribadi dari penulis

\section{UCAPAN TERIMA KASIH}

Pertama-tama kami ucapkan terima kasih atas kepada civitas akademika Universitas PGRI Madiun atas dukungannya sehingga artikel kami dapat di publish di Jurnal Kebijakan dan Manajemen Publik 


\section{REFERENCES}

Aryani, N. D. (2017). Pengembangan karir pegawai negeri sipil pada kantor komisi pemilihab umum (kpu) kota samarinda. EJournal Administrasi Bisnis, 5(3), 827839.

Fahmi, I. (2017). Manajemen Sumber Daya Manusia. Alfabeta.

Fathurrochman, I. (2017). PENGEMBANGAN KOMPETENSI PEGAWAI APARATUR SIPIL NEGARA (ASN) SEKOLAH TINGGI AGAMA ISLAM NEGERI (STAIN) CURUP MELALUI METODE PENDIDIKAN DAN PELATIHAN. Manajer Pendidikan, 11(21), 120-129.

Haryati, R. A. (2019). Analisis Pelaksanaan Program Pelatihan dan Pengembangan Karyawan: Studi Kasus Pada PT Visi Sukses Bersama Jakarta. Sekretari Dan Manajemen, 3(1), 91-98. https://doi.org/10.31294/widyacipta.v3i1.5185

Hasibuan, M. S. P. (2018). Manajemen Sumber Daya Manusia (Revisi). PT Bumi Aksara.

Kadarisman, M. (2018). Analisis pengembangan karier aparatur sipil negara di pemerintah kota depok. Civil Service, 12(2), 115-138.

Komara, E. (2019). Kompetensi profesional pegawai asn (aparatur sipil negara) di indonesia. Jurnal Indonesia Untuk Kajian Pendidikan, 4(1), 73-84.

Mangkunegara, A. P. (2017). Manajemen Sumber Daya Manusia Perusahaan. PT Remaja Rosdakarya.

Pranoto, J. S. (2016). Analisis motivasi karyawan di rumah makan warung kipung. Jurnal Manajemen Dan StartUp Bisnis, 1(4), 464-472.
Sarina. (2016). Strategi meningkatkan motivasi kerja aparatur dalam penyelenggaraan pemerintahan di kecamatan nunukan selatan kabupaten nunukan. EJournal Administrasi Negara, 4(1), 2249-2258.

Sukarno, A. (2018). Model pola pengembangan karir jabatan struktural pegawai negeri sipil pada pemerintah daerah di sulawesi. Administrasi Publik, 14(1), 71-86.

Torang, Syamsir. (2014). Organisasi \& Manajemen. Alfabeta.

Triatmanto, B. (2017). Analisis pengembangan karier yang dipengaruhi oleh kepemimpinan, budaya organisasi, dan prestasi kerja. Manajemen Dan Kewirausahaan, 5(2), $72-82$

Yusuf, B. (2015). Manajemen Sumber Daya Manusia Lembaga Keuangan Syariah. PT Raja Grafindo Persada.

Conflict of Interest Statement: The authors declare that the research was conducted in the absence of any commercial or financial relationships that could be construed as a potential conflict of interest.

Copyright (c) 2021 Erika Sari Yulianti, Satrijo Budiwibowo, Elly Astuti. This is an open-access article distributed under the terms of the Creative Commons Attribution License (CC $B Y)$. The use, distribution or repro-duction in other forums is permitted, provided the original author(s) and the copyright owner(s) are credited and that the original publication in this journal is cited, in accordance with accepted academic practice. No use, distribution or reproduction is permitted which does not comply with these terms. 